TOMASZ SROGOSZ

Krakowska Akademia im. Andrzeja Frycza Modrzewskiego

ORCID: 0000-0001-9753-8920

\title{
Kompetencje Rady Bezpieczeństwa ONZ w sprawach klimatycznych
}

\section{Competences of the UN Security Council on climate issues}

Originally, the UN Security Council was entrusted with the competences to maintain international peace and security as a state without armed conflict. These competencies have been extended and nowadays they include humanitarian and epidemiological issues. This is related to the changing scope of the notion of 'threat to peace', which already includes acts of violation of human rights, terrorist acts and epidemics. More and more attention is paid to threats resulting from climate change in international documents. An example is the new concept of the so-called climate conflict. The indicated threats have given rise to discussions on climate change in the UN Security Council. The debates also dealt with the question of possible competences of this body in climatic matters. Among the members of the UN Security Council, including permanent members, there was a clear difference of opinions. The resolutions 2349 (2017) and 2408 (2018) can be seen as a turning point in the discussion, in which the UN Security Council unanimously recognised the relationship between climate change and international security. The Security Council's competences in climate matters could be based on articles 33.2, 34, 38, 40, 41, 42 and 96 of the UN Charter. Despite the evolution of the approach to the climate dimension of security, the UN Security Council is still far from issuing a resolution on climate change including obligations on countries or companies, for instance in terms of reducing greenhouse gas emissions. As a member of the UN Security Council, Poland should work on consensus in this regard.

Keywords: Security Council, competences, climate, ecology, peace, security

Słowa kluczowe: Rada Bezpieczeństwa, kompetencje, klimat, ekologia, pokój, bezpieczeństwo

Rada Bezpieczeństwa (RB) to ciało Organizacji Narodów Zjednoczonych, na którym zgodnie z art. 24 Karty Narodów Zjednoczonych (KNZ) spoczywa główna odpowiedzialność za pokój i bezpieczeństwo międzynarodowe. Rozdziały VI-VIII i XII tej umowy nadają jej szereg kompetencji: może 
wydawać zalecenia i decyzje albo podejmować działania w przypadku „zagrożenia utrzymania międzynarodowego pokoju i bezpieczeństwa" (art. 33) czy „zagrożenia lub naruszenia pokoju bądź aktu agresji” (art. 39). Celem ich wszystkich jest „utrzymanie albo przywrócenie międzynarodowego pokoju i bezpieczeństwa".

Warunkiem określenia katalogu i zakresu kompetencji RB jest zatem zdefiniowanie międzynarodowego pokoju i bezpieczeństwa, które tuż po zakończeniu drugiej wojny światowej oznaczały jedynie zakaz użycia siły zbrojnej w rozumieniu art. 2 ust. 4 KNZ. Jak podkreślają Władysław Czapliński i Anna Wyrozumska, pojęcia pokój i bezpieczeństwo międzynarodowe interpretowane są rozszerzająco ${ }^{1}$. Idąc za tym stwierdzeniem, należy przyjąć, że ich znaczenie nie ma charakteru statycznego, tzn. obecny zakres semantyczny różni się od przyjętego w 1945 r. przez twórców KNZ. Na marginesie warto dodać, że brak normatywnego zdefiniowania pokoju i bezpieczeństwa międzynarodowego w KNZ jest fundamentem ponadczasowości tego dokumentu, ponieważ może on dzięki temu z powodzeniem znaleźć zastosowanie do zjawisk nieznanych podczas konferencji w San Francisco.

O ile po drugiej wojnie światowej zagrożenie dla międzynarodowego pokoju i bezpieczeństwa wiązało się z użyciem lub groźbą użycia siły zbrojnej, o tyle z czasem RB, korzystając ze swobody wykładni pojęcia pokój $i$ bezpieczeństwo międzynarodowe, stwierdzała takie zagrożenie $\mathrm{w}$ innych sytuacjach. Można do nich zaliczyć chociażby: rasistowską politykę rządu białej mniejszości w Rodezji (rezolucja 217/1965), politykę apartheidu w RPA (418/1977), popieranie terroryzmu przez Libię (741/1992, 748/1992), represjonowanie Kurdów w Iraku (688/1991), masowe naruszenia praw człowieka w Somalii (733/1992) i Rwandzie (929/1994) czy zamach terrorystyczny z 11 września 2001 r. $(1368 / 2001,1373 / 2001)^{2}$. W 2014 r. RB po raz pierwszy wskazała jako zagrożenie sytuację spoza polityki krajowej czy międzynarodowej, stwierdzając w rezolucji 2177/2014, że „bezprecedensowy zakres wybuchu eboli w Afryce stwarza zagrożenie dla międzynarodowego pokoju i bezpieczeństwa". W sprawach przywołanych powyżej skorzystała z kompetencji przewidzianych w rozdz. VII KNZ.

Rozpoczynając rozważania na temat ewentualnych kompetencji RB w sprawach klimatycznych, należy rozróżnić dwie sytuacje: konflikt zbrojny

1 W. Czapliński, A. Wyrozumska, Prawo międzynarodowe publiczne. Zagadnienia systemowe, C.H. Beck, Warszawa 2004, s. 374.

2 J. Barcik, T. Srogosz, Prawo międzynarodowe publiczne, C.H. Beck, Warszawa 2017, s. 663. 
(lub groźbę jego wybuchu) spowodowany czynnikami klimatycznymi oraz zmiany klimatyczne. W pierwszym przypadku RB bezdyskusyjnie dysponuje kompetencjami płynącymi z art. 39 i rozdz. VII KNZ. Bezsporność tej sytuacji powoduje, że nie będzie przedmiotem niniejszego artykułu, skoro od momentu wejścia w życie KNZ każdy konflikt zbrojny, niezależnie od podłoża, pozostaje w kręgu kompetencji RB. Problematyczne jest natomiast pytanie, czy RB ma kompetencje w sprawach zmian klimatycznych, które w przyszłości mogą być zarzewiem konfliktu zbrojnego lub katastrofy humanitarnej. Celem niniejszego artykułu jest zatem odpowiedź, czy na chwilę obecną można takowe wskazać, a jeżeli tak, to jakie środki może podjąć RB (z 41 czy może 42 art. KNZ?). Sytuację związaną z epidemią eboli w Afryce można traktować jako punkt zwrotny w ustaleniu zakresu kompetencji Rady, po raz pierwszy bowiem jako zagrożenie dla międzynarodowego pokoju i bezpieczeństwa potraktowana została siła przyrody. Aby odpowiedzieć na postawione powyżej pytania, w pierwszej kolejności należy się zastanowić nad tym, czy pojęcie zagrożenie pokoju, o którym mowa $\mathrm{w}$ art. $39 \mathrm{KNZ}$, poza epidemiologicznymi obejmuje także zagrożenia wynikające ze zmian klimatycznych. $Z$ uwagi na toczącą się w RB debatę na temat zmian klimatycznych poruszone kwestie nie mają jedynie waloru teoretycznego. Wprawdzie dyskusja nie została zakończona, a wątpliwości członków Rady nadal są widoczne, ale ze względu na przyspieszający proces globalnego ocieplenia należy zająć zdecydowane stanowisko $w$ tych kwestiach już teraz. Wydaje się, że za kilkadziesiąt, a nawet kilkanaście lat rozstrzygnięcie problemu kompetencji RB w sprawach klimatycznych można będzie uznać za spóźnione. Głos w tej sprawie powinna zabrać również Polska, będąca członkiem Rady w latach 2018-2019.

\section{Klimatyczne zagrożenia dla pokoju}

Zgodnie $\mathrm{z}$ art. $39 \mathrm{KNZ}$ RB stwierdza istnienie zagrożenia lub naruszenia pokoju bądź aktu agresji oraz udziela zaleceń lub decyduje, jakie środki w myśl art. 41 i 42 KNZ należy zastosować w celu utrzymania lub przywrócenia międzynarodowego pokoju lub bezpieczeństwa. $Z$ analizy rezolucji $\mathrm{RB}$ wynika, że stwierdza ona „zagrożenie międzynarodowego pokoju i bezpieczeństwa" (zob. np. rezolucję 2177/2014), nie ograniczając się jedynie do pokoju w rozumieniu art. $39 \mathrm{KNZ}$. Pojęcie zagrożenia pokoju z tego artykułu należy zatem interpretować szerzej. Tak jak powiedziano wcześniej, obejmuje ono nie tylko sytuacje związane z groźbą użycia siły zbrojnej lub jej użyciem, ale także zagrożenia dla bezpieczeństwa międzynarodowego niezwiązane z użyciem 
siły zbrojnej przez żadne państwo. Obecnie toczy się dyskusja, czy można do tego zaliczyć zagrożenia wynikające ze zmian klimatycznych. Treść rezolucji 2349/2017 RB (jednej z ostatnich) może być sygnałem, że tak. W pkt 26 uznano ,niekorzystne skutki zmian klimatycznych i zmian ekologicznych między innymi czynnikami wpływającymi na stabilność Regionu, włączając w to niedobór wody, susze, pustynnienie, degradację ziemi i brak bezpieczeństwa żywnościowego". Do tej pory Rada nie uznała jednak zagrożeń klimatycznych wprost za zagrożenia dla międzynarodowego pokoju i bezpieczeństwa, tak jak uczyniła to w przypadku epidemii eboli w 2014 r.

By odpowiedzieć na pytanie, czy zagrożenia klimatyczne mogą być rozumiane jako zagrożenie pokoju, o którym mowa w art. $39 \mathrm{KNZ}$, należy je pokrótce przybliżyć, ze szczególnym uwzględnieniem ich implikacji w sferze bezpieczeństwa międzynarodowego. Ich etiologia wiąże się ze zjawiskiem globalnego ocieplenia, które od wielu lat jest przedmiotem debaty naukowej. Pomijając dyskusyjną kwestię, czy przyczyną globalnego ocieplenia jest działalność człowieka, zmiany klimatu należy uznać za fakt niekwestionowany. W miarę obiektywnym źródłem w tym zakresie są raporty Międzyrządowego Panelu do spraw Zmian Klimatu (Intergovernmental Panel on Climate ChangeIPCC), w tym ostatni z 2014 r. ${ }^{3}$ Obserwowane i prognozowane zmiany klimatu obejmują ogrzewanie atmosfery oraz mórz i oceanów, czego następstwem jest kurczenie się kriosfery, podnoszenie poziomu mórz i oceanów, zakwaszenie ich, zmiany w cyrkulacji wody oraz ekstremalne zjawiska pogodowe w postaci susz, burz i intensywnych opadów. W ramach niniejszego artykułu nie omówiono tych zjawisk, ponieważ nie to jest jego celem. Zasygnalizowano je tu jedynie pokrótce jako tło zasadniczego wywodu. Nie ulega wątpliwości, że mogą one wpływać na bezpieczeństwo międzynarodowe, co zauważył już sekretarz generalny ONZ w raporcie dotyczącym zmian klimatu i możliwych implikacji w zakresie bezpieczeństwa ${ }^{4}$.

Następstwem zmian klimatycznych są i będą niedobory wody i żywności, spowolnienie gospodarcze, migracje, destabilizacja polityczna, wzrost liczby bezpaństwowców, zanik zasobów naturalnych lub odkrywanie nowych.

3 Climate change 2014. Synthesis report. Contribution of working groups I, II and III to the Fifth Assessment Report of the Intergovernmental Panel on Climate Change, ed. R.K. Pachauri, L.A. Meyer, Intergovernmental Panel on Climate Change, Geneva 2014, dostępny w internecie [dostęp: 14 V 2019]: <http://www.ipcc.ch/report/ar5/index.shtml>.

4 Climate change and its possible security implications. Report of the Secretary-General, United Nations General Assembly, A/64/350, 11 IX 2009, dostępny w internecie [dostęp: 14 V 2019]: <https://www.unhcr.org/protection/environment/543e $73 \mathrm{f} 69 /$ climate-changeits-possible-security-implications-report-secretary-general.html>. 
Nieodwracalne i coraz szybsze zmiany klimatu prowadzą i będą prowadzić w dalszej perspektywie do konfliktów klimatycznych, których namiastkę obserwujemy już teraz, chociażby na Bliskim Wschodzie i w Afryce. Problemy z wodą i żywnością, zanik lub odkrywanie zasobów naturalnych, susze, ekstremalne zjawiska pogodowe, powodzie, fale upałów czy też podnoszenie się poziomu mórz i oceanów mają bezpośredni związek ze zmianami klimatycznymi. W dalszej kolejności narastać będą skutki pośrednie w postaci spowolnienia gospodarczego, migracji, bezpaństwowców, destabilizacji politycznej państw słabych lub upadających (szczególnie w Afryce) czy też zaniku państwowości wysp na Oceanie Spokojnym. Konflikty klimatyczne będą konsekwencją skutków bezpośrednich i pośrednich. Samo pojęcie climate conflict zawiera $\mathrm{w}$ sobie uproszczenie. W istocie chodzi tu o tradycyjnie rozumiany międzynarodowy lub wewnętrzny konflikt zbrojny, którego podłożem są bezpośrednie i pośrednie skutki zmian klimatycznych. Destabilizacja polityczna państw afrykańskich i migracje ludności spowodowane zmianami klimatu mogą prowadzić do nasilenia się konfliktów zbrojnych w Afryce. Już teraz zauważalne jest tam zjawisko państw upadłych lub upadających wynikające z problemów natury postkolonialnej, jednak może być ono spotęgowane przez zmiany klimatu i związane z nimi migracje. Pojawiło się już pojęcie tzw. migrantów klimatycznych, czyli osób uciekających przed katastrofami naturalnymi, w tym powodziami (np. w Pakistanie w 2010 r. czy na Filipinach w 2013) albo zalewaniem wybrzeży przez ocean (np. na Tuvalu5). Międzynarodowa Organizacja do spraw Migracji zaproponowała nawet roboczą definicję migranta klimatycznego na potrzeby przyszłego projektu stosownej konwencji w tym zakresie ${ }^{6}$. Narastające konflikty o podłożu klimatycznym mogą wzmóc obecną falę migracji z Afryki i Bliskiego Wschodu do Europy, co w dalszej perspektywie może zagrażać stabilności politycznej państw Starego

5 W 2014 r. nowozelandzki sąd przyznał rodzinie $\mathrm{z}$ Tuvalu status uchodźców, powołując się m.in. na zmiany klimatu. R. Noack, Has the era of the 'climate change refugee' begun?, "The Washington Post” [online], 7 VIII 2014 [dostęp: 14 V 2019], dostępny w internecie: $<$ https://www.washingtonpost.com/news/worldviews/wp/2014/08/07/has-the-era-of-the-climate-change-refugee-begun/?noredirect $=$ on\&utm_term $=.79 \mathrm{e} 4657212 \mathrm{ac}>$.

6 „Environmental migrants are persons or groups of persons who, predominantly for reasons of sudden or progressive change in the environment that adversely affects their lives or living conditions, are obliged to leave their habitual homes, or choose to do so, either temporarily or permanently, and who move either within their country or abroad". Migration, Environment and Climate Change (MECC) Division. Evidence for policy (MECLEP). Glossary, International Organization for Migration, Geneva 2014, dostępny w internecie [dostęp: 14 V 2019]: <https://publications.iom.int/system/files/pdf/meclep_ glossary_en.pdf?language $=\mathrm{en}>$. 
Kontynentu. Następny potencjalny czynnik konfliktogenny to odkrywanie nowych złóż zasobów naturalnych na skutek topnienia lodu na biegunach. Już teraz mówi się o nowej zimnej wojnie o Arktykę. Państwa sąsiadujące z tym obszarem wysuwają roszczenia mające na celu zapewnienie sobie możliwości eksploracji i eksploatacji jego zasobów po skurczeniu się pokrywy lodowej. Może to prowadzić do zagrożenia międzynarodowego pokoju i bezpieczeństwa, w tym konfliktu zbrojnego ${ }^{7}$. Takie same skutki może wywołać sytuacja odwrotna, tzn. kurczenie się ilości zasobów naturalnych na niektórych obszarach (np. wody) w wyniku zmian klimatycznych ${ }^{8}$. Kolejnym następstwem zmian klimatu związanym z podnoszeniem się poziomu mórz i oceanów będą spowodowane cofaniem się linii brzegowej zmiany terytorialne w państwach wyspiarskich (Kiribati, Tuvalu, Nauru) oraz nadmorskich. Niektórzy członkowie ONZ mogą w związku z tym stracić status państwa9. Wcześniej natomiast można będzie mówić o szkodach poniesionych na skutek globalnego ocieplenia, rodzących odpowiedzialność prawnomiędzynarodową państw, które $\mathrm{w}$ znaczącym stopniu się do niego przyczyniają ${ }^{10}$. Zmiany terytorialne związane z cofaniem się linii brzegowej mogą także prowadzić do konfliktów granicznych.

Charakterystyka wynikających ze zmian klimatu zagrożeń dla międzynarodowego pokoju i bezpieczeństwa nie jest już tylko przedmiotem teoretycznych rozważań przedstawicieli nauk politologicznych lub prawnych. Skutki globalnego ocieplenia są coraz bardziej widoczne w stosunkach międzynarodowych, chociażby w postaci migracji klimatycznych, problemów państw wyspiarskich, zimnej wojny o zasoby naturalne czy też katastrof humanitarnych. Stają się zatem tematem debaty na forach międzynarodowych. Unia Europejska w raporcie pt. Zmiany klimatyczne a bezpieczeństwo międzynarodowe wyróżniła w tym kontekście następujące konflikty: o zasoby, graniczne i terytorialne, na tle migracyjnym, spowodowane zwiększeniem niestabilności w krajach słabych lub upadających, o zasoby energetyczne i kontrolę

7 J. Symonides, Wyznaczanie granic obszarów morskich w Arktyce. Spory delimitacyjne i ich rozwiazanie, [w:] Państwo i terytorium w prawie międzynarodowym, red. J. Menkes E. Cała-Wacinkiewicz, C.H. Beck, Warszawa 2015, s. 489.

8 Zob. np. P.H. Gleick, Water and conflict. Fresh water resources and international security, „International Security” 1993, vol. 18, No. 1, s. 79-112.

9 Można wyobrazić sobie chociażby sytuację, w której na skutek podniesienia się poziomu oceanu państwo wyspiarskie traci terytorium i ludność w latach, gdy jest członkiem RB.

10 Zob. H. Stallard, Turning up the heat on Tuvalu. An assessment of potential compensation for climate change in accordance with state responsibility under international law, „Cantenbury Law Review” 2009, vol. 15, s. 163-203. 
nad nimi oraz między państwami odpowiedzialnymi za zmiany klimatu a najbardziej dotkniętymi tymi zmianami ${ }^{11}$. W debacie międzynarodowej można zatem zauważyć tendencję do łączenia zmian klimatu i ich skutków z międzynarodowym pokojem i bezpieczeństwem. W chwili obecnej jest to raczej ewoluujące spojrzenie na reinterpretację pojęcia bezpieczeństwa, o którym mowa w artykułach 1, 24 i $39 \mathrm{KNZ}^{12}$. Nie pozostaje ono jednak bez echa w samej RB, która zagrożeniom związanym z globalnym ociepleniem poświęciła cztery debaty, w tym dwie w formule Arria.

\section{Debaty w Radzie Bezpieczeństwa ONZ}

Pierwsze posiedzenie RB dotyczące zmian klimatu zwołano 17 kwietnia 2007 r. na wniosek Wielkiej Brytanii ${ }^{13}$. Do udziału w obradach, choć bez prawa głosu, dopuszczono też w trybie art. 37 Provisional rules of procedure $e^{14}$ państwa spoza Rady, ale zdaniem jej członków szczególnie zainteresowane zmianami klimatu ${ }^{15}$. Na początku spotkania przewodnicząca Rady Margaret Beckett z Wielkiej Brytanii podniosła, że za przeprowadzeniem na tym forum dyskusji o skutkach zmian klimatu przemawiają ich implikacje w sferze bezpieczeństwa. Dodała jednocześnie, że debata nie dotyczy kompetencji innych organów i agencji ONZ, ale tylko i wyłącznie RB, która jest w stanie

11 Climate change and international security. Paper from the High Representative and the European Commission to the European Council, European Commission, [b.d.m.w.], s. 5-8, dostępny w internecie [dostęp: $14 \mathrm{~V}$ 2019]: <http://www.consilium.europa.eu/ media/30862/en_clim_change_low.pdf $>$.

12 M. Kenig-Witkowska, Międzynarodowe prawo środowiska. Wybrane zagadnienia systemowe, Wolters Kluwer Polska, Warszawa 2011, s. 27.

13 Letter dated 5 April 2007 from the Permanent Representative of the United Kingdom of Great Britain and Northern Ireland to the United Nations addressed to the President of the Security Council, United Nations Security Council, S/2007/186, dostępny w internecie [dostęp: $14 \mathrm{~V}$ 2019]: <https://www.securitycouncilreport.org/atf/cf/\%7B65BFCF9B-6D27-4E9C-8CD3-CF6E4FF96FF9\%7D/CC\%20S2007\%20186.pdf>. Skład RB w 2007 r.: Belgia, Chiny, Francja, Ghana, Indonezja, Katar, Kongo, Panama, Peru, Republika Południowej Afryki, Rosja, Słowacja, Stany Zjednoczone, Wielka Brytania i Włochy.

14 Provisional rules of procedure. Chapter VI: Conduct of business, „United Nations Security Council” [online, dostęp: 14 V 2019], dostępny w internecie: <https://www.un.org/ securitycouncil/content/rop/chapter-6>.

15 Były to: Argentyna, Australia, Bangladesz, Barbados, Boliwia, Brazylia, Dania, Egipt, Filipiny, Holandia, Indie, Islandia, Izrael, Japonia, Kanada, Komory, Korea Południowa, Kostaryka, Kuba, Liechtenstein, Malediwy, Mauritius, Meksyk, Mikronezja, Namibia, Niemcy, Norwegia, Nowa Zelandia, Pakistan, Palau, Papua Nowa Gwinea, Republika Zielonego Przylądka, Singapur, Sudan, Szwajcaria, Tuvalu, Ukraina, Wenezuela, Wyspy Marshalla i Wyspy Salomona. 
podjąć w przedmiotowej sprawie najskuteczniejsze działania ${ }^{16}$. W trakcie debaty zarysowały się trzy stanowiska: dopuszczające uprawnienie RB do podjęcia odpowiednich działań w sprawach klimatycznych, zdecydowanie negujące taką możliwość oraz neutralne, czyli nienawiązujące do kwestii mandatu Rady ${ }^{17}$. Możliwość działania RB w sprawach zmian klimatu dopuściły Unia Europejska i państwa do niej kandydujące, reprezentowane przez Niemcy (z wyłączeniem Wielkiej Brytanii i Belgii). Zdaniem Niemiec zmiany klimatu wpływają na bezpieczeństwo międzynarodowe, dlatego też powinny być przedmiotem conflict prevention, o której mowa w rezolucji 1625/2005. Podobne stanowisko zajęły Kongo, Norwegia i Panama. Dalej w swych postulatach poszły państwa wyspiarskie Oceanu Spokojnego reprezentowane przez Papuę Nową Gwineę (Pacific Small Island Developing States), co z pewnością wynika z ich specyficznych problemów związanych z groźbą utraty terytorium na skutek wzrostu poziomu oceanu. Zdaniem przedstawiciela Papui Nowej Gwinei zagrożenia klimatyczne w regionie porównywalne są z zagrożeniem konfliktem zbrojnym, dlatego też RB jest odpowiednim organem do zajęcia się sprawami ekologicznymi. Przedstawiciel Tuvalu stwierdził, że Rada powinna zajmować się environmental security, wzywając jednocześnie do natychmiastowego działania i odpowiedniej zmiany KNZ w tym zakresie. Przeciwko możliwości objęcia zmian klimatu mandatem RB opowiedziały się Chiny, Rosja oraz reprezentanci Grupy 77 i Ruchu Państw Niezaangażowanych, wśród argumentów podnosząc m.in. to, że zmiany klimatu powinny być i są przedmiotem współpracy w ramach zrównoważonego rozwoju. Społeczność międzynarodowa wypracowała ich zdaniem mechanizmy współdziałania w tym zakresie, chociażby w oparciu o postanowienia Ramowej konwencji Narodów Zjednoczonych w sprawie zmian klimatu oraz protokołu z Kioto ${ }^{18}$. Odpowiednimi forami ONZ w tym zakresie pozostaja według tych państw Rada Społeczno-Gospodarcza i Zgromadzenie Ogólne,

$165663^{\text {rd }}$ meeting, Tuesday, 17 April 2007, 10 a.m., New York, United Nations Security Council, S/PV.5663, dostępny w internecie [dostęp: 14 V 2019]: <https://www.securitycouncilreport.org/atf/cf/\%7B65BFCF9B-6D27-4E9C-8CD3-CF6E4FF96FF9\%7D/ Ener\%20SPV\%205663.pdf>.

17 Tamże; 5663 ${ }^{\text {rd }}$ meeting, Tuesday, 17 April 2007, 3 p.m., New York, United Nations Security Council, S/PV.5663 (Resumption 1), dostępny w internecie [dostęp: 14 V 2019]: $<$ https://www.securitycouncilreport.org/atf/cf/\%7B65BFCF9B-6D27-4E9C-8CD3-CF6E4FF96FF9\%7D/Ener\%20SPV\%205663\%20Res\%201.pdf>.

18 Podpisana 9 V 1992 r. w Nowym Jorku Ramowa konwencja Narodów Zjednoczonych w sprawie zmian klimatu (UNTS, vol. 1771) weszła w życie 21 III 1994 r., a w stosunku do Polski - 26 X 1994 r. Protokół z Kioto do konwencji (UNTS, vol. 2303), podpisany 11 XII 1997 r., wszedł w życie 16 II 2005 r., także w stosunku do Polski. 
a przyznanie dodatkowego mandatu $\mathrm{RB}$ naruszałoby równowagę między organami ONZ i prowadziło do deprecjonowania jej pozostałych instytucji. Neutralne stanowisko w debacie na temat zmian klimatu zajęły m.in. Stany Zjednoczone, Japonia, Korea Południowa, Kanada i Izrael.

Pierwsza dyskusja uwidoczniła wyraźny podział wśród społeczności międzynarodowej co do kompetencji RB, także między stałymi członkami tego gremium. Cztery lata później podjęto więc jeszcze jedną próbę negocjacji i 20 lipca 2011 r. pod przewodnictwem Niemiec odbyła się debata pt. „Maintenance of international peace and security: the impact of climate change" 19 . Bardziej wyraźne stanowisko zajęly tym razem Stany Zjednoczone, uznając, że RB powinna zajmować się kwestiami zmian klimatu $w$ ramach działań na rzecz utrzymania pokoju. Na drodze do przyznania Radzie takiego mandatu ponownie stanęły jednak Chiny i Rosja. Pekin wciąż pozostawał na stanowisku, że zmiany klimatu należy rozpatrywać w kontekście zrównoważonego rozwoju, a przedstawiciel Moskwy wyraził zaniepokojenie, że nadanie Radzie kompetencji w sprawach klimatycznych może prowadzić do upolitycznienia problemów ekologicznych i pogłębienia sporów między państwami. Instrumentem do rozwiązywania tych kwestii powinna pozostać zdaniem Rosji ramowa konwencja w sprawie zmian klimatu. Podobne stanowisko zajęły Egipt (w imieniu Ruchu Państw Niezaangażowanych), Argentyna (w imieniu Grupy $77^{20}$ ), Barbados (w imieniu Wspólnoty Karaibskiej) oraz Kuwejt (w imieniu państw arabskich). Ich zdaniem debata na temat zmian klimatu w RB w żadnym wypadku nie może stwarzać precedensu w zakresie modyfikacji kompetencji organów ONZ. Uważają, że w sprawach objętych zrównoważonym rozwojem właściwymi organami pozostają Zgromadzenie Ogólne i Rada Społeczno-Gospodarcza. Stanowiska państw zaprezentowane w debacie w 2007 r. nie uległy więc zasadniczej zmianie - wszystkie podtrzymywały swoją argumentację. Z perspektywy Rzeczypospolitej Polskiej interesujące jest wystąpienie jej przedstawiciela Łukasza Zielińskiego, który zwrócił uwagę na wynikające ze zmian

19 W 2011 r. w skład RB wchodziły: Bośnia i Hercegowina, Brazylia, Chiny, Francja, Gabon, Indie, Kolumbia, Liban, Niemcy, Nigeria, Portugalia, Republika Południowej Afryki, Rosja, Stany Zjednoczone i Wielka Brytania. Udział w debacie wzięły również: Argentyna, Australia, Bangladesz, Barbados, Belgia, Boliwia, Chile, Dania, Egipt, Ekwador, Fidżi, Filipiny, Finlandia, Ghana, Hiszpania, Honduras, Iran, Irlandia, Islandia, Izrael, Japonia, Kanada, Kazachstan, Kenia, Kirgistan, Korea Południowa, Kostaryka, Kuba, Kuwejt, Luksemburg, Meksyk, Nauru, Nowa Zelandia, Pakistan, Palau, Papua Nowa Gwinea, Peru, Polska, Salvador, Singapur, Słowenia, Sudan, Tanzania, Turcja, Węgry i Włochy.

20 Kostaryka, Liban i Singapur uznały ograniczoną rolę RB w sprawach zmian klimatu. 
klimatu problemy w sferze bezpieczeństwa, tj. kwestie żywności, wody, rywalizacji o zasoby czy destabilizację polityczną. Jego zdaniem wymagają one natychmiastowego działania w skali globalnej, ,outside the environmental box" - globalnego zarządzania ryzykiem, które wzmocniłoby międzynarodową współpracę $\mathrm{w}$ zakresie monitorowania zagrożeń dla bezpieczeństwa związanych ze zmianami klimatu. Polska nie zajęła w debacie zdecydowanego stanowiska w kwestii mandatu RB, ale można powiedzieć, że pośrednio zaakceptowała jego potencjalną modyfikację w kierunku zarządzania ryzykiem i monitorowania zagrożeń dla bezpieczeństwa. $Z$ uwagi na postępujące problemy związane z podnoszeniem poziomu mórz i oceanów gorącymi zwolennikami przyznania Radzie kompetencji w sprawach klimatycznych pozostawały wciąż państwa wyspiarskie Oceanu Spokojnego, tym razem wsparte przez Stany Zjednoczone i Kanadę. Co ciekawe, bardziej zachowawcze stanowisko niż w 2007 r. zaprezentowała UE ${ }^{21}$.

Debata z 2011 r. nie przyniosła żadnych zmian. Nadal zauważalny jest wyraźny podział na państwa wyspiarskie Pacyfiku (wspierane m.in. przez Kanadę, Stany Zjednoczone czy Australię) oraz liczną grupę afrykańskich i azjatyckich państw arabskich i postkolonialnych (wspieranych przez dwóch stałych członków RB - Rosję i Chiny). Uogólniając, można stwierdzić, że państwa zachodnie przychylają się do możliwości poszerzenia kompetencji RB o kwestie klimatyczne, natomiast państwa azjatyckie, afrykańskie i południowoamerykańskie $\mathrm{w}$ większości stoją na straży dotychczasowego rozróżnienia kompetencji organów ONZ w oparciu o współpracę w zakresie zrównoważonego rozwoju oraz bezpieczeństwa. Wyrazem tego podziału jest oświadczenie przewodniczącego RB wydane 20 lipca 2011 r. z jej upoważnienia. Uznał on odpowiedzialność Zgromadzenia Ogólnego i Rady Społeczno-Gospodarczej za sprawy związane ze zrównoważonym rozwojem, w tym zmianami klimatu. Jednocześnie stwierdził, że podstawowym instrumentem jest w tym zakresie ramowa konwencja w sprawie zmian klimatu, a organy ONZ powinny zajmować się tym problemem w ramach swoich kompetencji, włączając $\mathrm{w}$ to możliwe implikacje w sferze bezpieczeństwa. W oświadczeniu podkreślono w związku z tym, że w dłuższej perspektywie potencjalne negatywne skutki zmian klimatu mogą pogłębiać pewne zagrożenia dla międzynarodowego pokoju i bezpieczeństwa, w szczególności w związku

21 Security Council, in statement, says 'contextual information' on possible security implications of climate change important when climate impacts drive conflict, „United Nations" [online], 20 VII 2011 [dostęp: 14 V 2019], dostępny w internecie: <https://www. un.org/press/en/2011/sc10332.doc.htm>. 
$\mathrm{z}$ utratą terytorium przez niektóre państwa w wyniku wzrostu poziomu mórz i oceanów. Analiza konfliktów przez RB powinna obejmować w szczególności możliwe implikacje zmian klimatu w sferze bezpieczeństwa ${ }^{22}$. Treść oświadczenia przewodniczącego Rady odzwierciedla zatem różne stanowiska w łonie tego organu i nie wynikają z niego jednoznacznie kompetencje $\mathrm{RB} w$ zakresie spraw klimatycznych. $Z$ drugiej strony nie neguje ono takiego mandatu, pozostawiając kwestię otwartą, w szczególności gdy chodzi o rozwiązywanie konkretnych konfliktów. Mimo wszystkich wątpliwości należy zauważyć, że RB z pewnością dostrzegła w trakcie wspomnianych debat implikacje zmian klimatu w sferze bezpieczeństwa międzynarodowego. Można tu mówić o bezpieczeństwie klimatycznym ${ }^{23}$.

Po oświadczeniu przewodniczącego RB z 20 lipca 2011 r. dyskusja na temat roli Rady w sprawach zmian klimatycznych przeniosła się na poziom nieformalny, tzn. spotkania organizowane w formule Arria ${ }^{24}$. Jak dotąd odbyły się one dwukrotnie: 30 czerwca 2015 r. z inicjatywy Wielkiej Brytanii i Pakistanu, gdy tematem były zmiany klimatu jako threat multiplier dla bezpieczeństwa globalnego, oraz 22 kwietnia 2016 r. na wniosek Hiszpanii i Malezji, gdy rozmawiano o wodzie, pokoju i bezpieczeństwie. Na żadnym z tych spotkań nie zdołano jednak przekonać partnerów do zmiany stanowiska w sprawie rozszerzenia kompetencji $\mathrm{RB}^{25}$. Nadal widoczna była linia podziału między

22 „The Security Council reaffirms its primary responsibility under the Charter of the United Nations for the maintenance of international peace and security. The Council stresses the importance of establishing strategies of conflict prevention. The Security Council recognizes the responsibility for sustainable development issues, including climate change, conferred upon the General Assembly and the Economic and Social Council. [...] The Security Council expresses its concern that possible adverse effects of climate change may, in the long run, aggravate certain existing threats to international peace and security. [...] conflict analysis and contextual information on, inter alia, possible security implications of climate change is important, when such issues are drivers of conflict, represent a challenge to the implementation of Council mandates or endanger the process of consolidation of peace". Statement by the President of the Security Council, United Nations Security Council, 20 VII 2011, S/PRST/2011/15, dostępny w internecie [dostęp: 14 V 2019]: <https://www.securitycouncilreport.org/atf/cf/\%7B65BFCF9B-6D27-4E9C8CD3-CF6E4FF96FF9\%7D/CC\%20SPRST\%202011\%205.pdf>.

23 Zob. T. Srogosz, Bezpieczeństwo klimatyczne a prawo międzynarodowe, „Zeszyty Naukowe Uczelni Jana Wyżykowskiego. Studia z Nauk Społecznych” 2019, z. 11, s. 67-88.

$24 \mathrm{Na}$ temat formuły Arria zob. Working methods handbook. „Arria-formula” meetings, „United Nations Security Council” [online, dostęp: 14 V 2019], dostępny w internecie: $<$ https://www.un.org/securitycouncil/content/arria-formula $>$.

25 Press conference on impact of climate change on Marshall Islands, „United Nations” [online], 15 II 2013 [dostęp: 14 V 2019], dostępny w internecie: <http://www.un.org/ press/en/2013/130215_MI.doc.htm>. 
Stanami Zjednoczonymi, UE i państwami wyspiarskimi Oceanu Spokojnego, które za tym optowały, a przeciwnymi zmianom Rosją, Chinami i Grupą 77 (chociaż widoczny jest trend do wyłamywania się państw afrykańskich, coraz bardziej odczuwających skutki globalnego ocieplenia) ${ }^{26}$.

Dyskusja w łonie RB nie przyniosła żadnych wymiernych rezultatów poza wnioskiem, że nie ma ona obecnie kompetencji w sprawach ekologicznych. Inna konkluzja byłaby uprawniona tylko wtedy, gdyby w trakcie negocjacji swoje stanowisko zmieniły Rosja, Chiny i Grupa 77. Na tym można byłoby zakończyć niniejsze rozważania, gdyby nie fakt, że okazję do ponownego zabrania głosu w omawianej kwestii miała Polska, jako niestały członek RB. Dotychczasowy brak zgody wśród członków Rady nie zwalnia od dalszej debaty, która może w prowadzić do zmiany stanowisk i konsensusu (potwierdzającego lub negującego przedmiotowe kompetencje tego organu). Na przedstawioną debatę rzutuje także fakt, który mógł umknąć uwadze - uchwała RB w sprawie rezolucji $2349(2017)^{27}$.

\section{Punkt zwrotny?}

W punkcie 26 rezolucji nr 2349 (2017) w sprawie regionu jeziora Czad RB uznaje zmiany klimatu za jedno z zagrożeń dla stabilności regionu, przy czym stabilność należy tu rozumieć jako bezpieczeństwo ${ }^{28}$. Tym samym można stwierdzić, że Rada uznała wpływ zmian klimatu na bezpieczeństwo międzynarodowe, gdyż region ten obejmuje kilka państw: Kamerun, Czad, Niger i Nigerię. Co istotne, rezolucja została przyjęta jednomyślnie, również za aprobatą państw, które w debatach na temat zmian klimatu sprzeciwiały się poszerzaniu kompetencji RB, tzn. Chin i Rosji. Bez znaczenia jest

26 D. Warren, N. Utterback, United Nations Security Council holds special meeting on climate change, „Climate Law Blog” [online], 7 VII 2015 [dostęp: 14 V 2019], dostępny w internecie: <http://blogs.law.columbia.edu/climatechange/2015/07/07/united-nations-security-council-holds-special-meeting-on-climate-change/\#more-3336>.

27 Resolution 2349 (2017). Adopted by the Security Council at its $7911^{\text {th }}$ meeting on 31 March 2017, United Nations Security Council, S/RES/2349 (2017), dostępny w internecie [dostęp: 14 V 2019]: <https://www.securitycouncilreport.org/atf/cf/\%7B65BFCF9B-6D27-4E9C-8CD3-CF6E4FF96FF9\%7D/S_RES_2349.pdf >.

28 „The adverse effects of climate change and ecological changes among other factors on the stability of the Region, including through water scarcity, drought, desertification, land degradation, and food insecurity, and emphasises the need for adequate risk assessments and risk management strategies by governments and the United Nations relating to these factors". Tamże. 
tutaj wygłoszona przed głosowaniem uwaga przedstawiciela Rosji Jewgienija Zagajnowa, że tekst rezolucji jest niedopracowany (unrefined), a także sceptyczne uwagi Stanów Zjednoczonych wobec pkt 26, wynikające $\mathrm{z}$ wycofania się Waszyngtonu z paryskiego porozumienia klimatycznego z 2015 r. ${ }^{29}$

Czy powyższa rezolucja może być traktowana jako punkt zwrotny w kwestii kompetencji RB w sprawach klimatycznych? Jak wiadomo, w kwestiach kluczowych dla bezpieczeństwa międzynarodowego jednomyślność członków RB (zwłaszcza stałych) nie jest łatwa do osiągnięcia. Fakt, że doszło do tego w tym przypadku, podkreśla znaczenie pkt 26 . Nie można byłoby tego traktować jako momentu zwrotnego czy precedensu, gdyby nie jednomyślne przyjęcie rezolucji 2408 (2018) w sprawie Somalii z 27 marca 2018 r. RB przywołała w niej oświadczenie przewodniczącego z 20 lipca 2011 r., a następnie w preambule w sposób zbliżony do pkt 26 rezolucji 2349 (2017) uznała zmiany klimatu za czynnik destabilizujący sytuację polityczną w Somalii ${ }^{30}$. Debaty sprzed kliku lat przyniosły zatem w ciągu ostatnich miesięcy wymierny skutek w postaci pierwszych odniesień do zmian klimatu w rezolucjach RB. Organ ten zaczął szerzej traktować pojęcie zagrożenie pokoju z art. 39 $\mathrm{KNZ}$, obejmując nim poza zagrożeniami stricte militarnymi, epidemiologicznymi czy humanitarnymi te, które wynikają ze zmian klimatu. Trudno na razie mówić o wykonywaniu kompetencji RB w sprawach klimatycznych, ale poczyniono w tym kierunku pierwsze kroki, szczególnie przy okazji określania mandatu misji pokojowej UNOSOM. W ramach konkluzji można zatem pokusić się o zaproponowanie pewnych kompetencji Rady, prawdopodobne jest bowiem, że w niedalekiej przyszłości jej członkom przyjdzie głosować nad rezolucją, która może je urzeczywistnić.

29 Security Council strongly condemns terrorist attacks, other violations in Lake Chad Basin region, unanimously adopting resolution 2349 (2017), „United Nations” [online], 31 III 2017 [dostęp: 14 V 2019], dostępny w internecie: <https://www.un.org/press/en/2017/ sc12773.doc.htm>; In hindsight. The Security Council and climate change - an ambivalent relationship, „Security Council Report” [online], 31 VII 2017 [dostęp: 14 V 2019], dostępny w internecie: <http://www.securitycouncilreport.org/monthly-forecast/2017-08/ the_security_council_and_climate_change_an_ambivalent_relationship.php $>$.

30 „The adverse effects of climate change, ecological changes and natural disasters among other factors on the stability of Somalia, including through drought, desertification, land degradation, and food insecurity, and emphasising the need for adequate risk assessments and risk management strategies by governments and the United Nations relating to these factors". Resolution 2408 (2017). Adopted by the Security Council at its $8215^{\text {th }}$ meeting on 27 March 2018, United Nations Security Council, S/RES/2408 (2018), dostępny w internecie [dostęp: 14 V 2019]: <https://undocs.org/S/RES/2408(2018)>. 


\section{Proponowane kompetencje Rady Bezpieczeństwa ONZ}

Ogólne uprawnienia RB do podejmowania działań w sferze pokoju i bezpieczeństwa międzynarodowego wynikają z art. $39 \mathrm{KNZ}$. Rada stwierdza istnienie zagrożenia lub naruszenia pokoju bądź aktu agresji oraz udziela zaleceń lub decyduje, jakie środki należy zastosować w myśl art. 41 i 42 KNZ w celu utrzymania lub przywrócenia międzynarodowego pokoju lub bezpieczeństwa. Szczegółowe kompetencje przewidziane zostały w pozostałych przepisach rozdz. VII (w szczególności art. 41 i 42) oraz VI (art. 96) KNZ. Jak zasygnalizowano wcześniej, początkowo RB dysponowała jedynie kompetencjami w sprawach bezpieczeństwa militarnego, ale z czasem zakres pojęcia $z a-$ grożenie pokoju z art. $39 \mathrm{KNZ}$ był rozszerzany. Jeżeli przyjąć, że należy pod nim rozumieć również bezpieczeństwo klimatyczne, to trzeba się zastanowić nad ewentualnymi kompetencjami Rady, gdy stwierdzi ona zagrożenie pokoju w sytuacji negatywnych skutków zmian klimatu. Jakie środki mogą okazać się adekwatne w stosunku do tak specyficznego zagrożenia pokoju? Czy w grę wchodzą tylko instrumenty określone w art. $41 \mathrm{KNZ}$ (niemilitarne), czy także te $\mathrm{z}$ art. 42 (militarne)?

W pierwszej kolejności wskazuje się, że RB może skorzystać z miękkich środków wskazanych w rozdziale VI KNZ: wezwania stron do rozstrzygnięcia sporu (art. 33 ust. 2), zbadania sytuacji (art. 34) czy zaleceń (art. 38) ${ }^{31}$. Narzędzia te dotyczą pokojowego załatwiania konfliktów i nie mają charakteru wiążącego. Nietrudno wyobrazić sobie tego rodzaju spory w sprawach związanych ze zmianami klimatu. Ich zalążek uwidocznił się już chociażby podczas omówionych wyżej debat na forum RB, a istota już teraz sprowadza się do kwestii odpowiedzialności za zmiany klimatu. Państwa wyspiarskie Oceanu Spokojnego podnoszą, że ich los spoczywa w rękach przywódców państw, które w największym stopniu przyczyniają się do emisji gazów cieplarnianych. Zarzewie sporu najbardziej obrazowo zaprezentował przedstawiciel Kuby ${ }^{32}$. W przyszłości może dojść na przykład do próby wysuwania

31 Zob. D. Warren, Climate change and international peace and security. Possible roles for the U.N. Security Council in addressing climate change, Columbia Law School, Sabin Center for Climate Change Law, New York 2017, s. 10, dostępny w internecie [dostęp: 14 V 2019]: <https://web.law.columbia.edu/sites/default/files/microsites/climate-change/warren_-_cc_and_international_peace_and_security_-_roles_for_the_un_security_ council.pdf $>$.

32 „Climate change is undoubtedly one of the most serious and imminent dangers threatening the survival of humankind. Paradoxically, the States most affected and in the worst position to adapt to the negative consequences of climate change, in particular small 
przez państwa wyspiarskie roszczeń w stosunku do państw wysoko uprzemysłowionych. Na problem ten zwróciła uwagę Komisja Europejska. W skierowanym do Rady Europejskiej raporcie pt. Zmiany klimatyczne a bezpieczeństwo międzynarodowe wśród sporów klimatycznych wyróżniła m.in. konflikty między „państwami odpowiedzialnymi za zmiany klimatyczne a państwami najbardziej dotkniętymi tymi zmianami"33.

Drugim rodzajem środków miękkich (tzn. niemających charakteru sankcji) są przewidziane w art. $40 \mathrm{KNZ}$ zarządzenia tymczasowe. Można wyobrazić sobie sytuację, w której RB potępia naruszanie przez dane państwo międzynarodowych zobowiązań dotyczących zmian klimatu i wzywa je do ratyfikowania odpowiednich umów międzynarodowych lub ich wykonywania $^{34}$. Należy jednak podkreślić, że w aktualnym stanie prawnym nie ma żadnej ogólnej zasady prawa międzynarodowego, która zobowiązywałaby wszystkie państwa na świecie do ograniczenia emisji gazów cieplarnianych. Protokół z Kioto nakłada zobowiązania redukcyjne wyłącznie na państwa rozwinięte, czego w żadnej mierze nie zmieniło porozumienie paryskie z $2015 \mathrm{r}$. Nieskuteczność międzynarodowych zobowiązań w tym zakresie potęgowana jest przez negatywne stanowisko Stanów Zjednoczonych, co sprawia, że kompetencja RB polegająca na wzywaniu do realizacji zobowiązań międzynarodowych obejmujących przeciwdziałanie zmianom klimatu ma raczej charakter hipotetyczny i perspektywiczny.

Trzecim rodzajem środków miękkich jest wniosek o wydanie opinii doradczej w sprawie zmian klimatu (art. $96 \mathrm{KNZ}$ ), z którym RB może wystąpić do Międzynarodowego Trybunału Sprawiedliwości. Za wzór posłużyć może sprawa legalności użycia broni jądrowej, w której zresztą poruszone zostały kwestie ochrony środowiska ${ }^{35}$. Pytanie mogłoby dotyczyć legalności

island developing States and African countries, are the least responsible for the problem. On the contrary, developed countries' emissions account for 76 per cent of greenhouse gas emissions, which continue to grow. One billion people in the first world wastefully consume half the planet's energy while 2 billion poor people lack electricity. Thirty countries consume 80 per cent of the fuel that the world produces. Developed countries therefore bear the main responsibility for repaying the debt historically owed to our planet's ecosystem". 6587 th meeting Wednesday, 20 July 2011, 3 p.m., New York, United Nations Security Council, S/PV.6587 (Resumption 1), s. 11, dostępny w internecie [dostęp: 14 V 2019]: <https://www.securitycouncilreport.org/atf/cf/\%7B65BFCF9B-6D27-4E9C-8CD3-CF6E4FF96FF9\%7D/CC\%20SPV\%206587\%20RES1.pdf>.

33 Climate change and international security..., s. 8.

34 D. Warren, Climate change..., s. 10.

35 Legality of the threat or use of nuclear weapons. Advisory opinion of 8 July 1996, International Court of Justice, s. 226 (ICJ Reports). 
emisji gazów cieplarnianych w kontekście zasady dobrosąsiedztwa, która w przypadku zmian klimatu nie powinna ograniczać się jedynie do państw mających wspólną granicę ${ }^{36}$.

W ramach swoich kompetencji RB może też powołać organ pomocniczy w postaci komitetu ds. zmian klimatu, którego zadaniem byłoby monitorowanie wykonywania zobowiązań w sprawach klimatycznych na poziomie krajowym ${ }^{37}$.

Kolejną grupą instrumentów w dyspozycji RB są środki twarde, czyli sankcje. O ile łatwo wyobrazić sobie sankcje niewojskowe, o których mowa w art. $41 \mathrm{KNZ}$, o tyle zarządzenie sankcji wojskowych (art. 42) może być problematyczne, chociażby z uwagi na to, że ich realizacja prowadzi do degradacji środowiska ${ }^{38}$. Sankcje mogą być nałożone przede wszystkim na państwo, które nie stosuje się do zobowiązań dotyczących ochrony klimatu, w szczególności emitenta gazów cieplarnianych. Do instrumentów RB można zaliczyć: embargo, zawieszenie współpracy naukowej i technicznej, blokadę operacji finansowych, zobowiązanie do ratyfikowania umów międzynarodowych dotyczących przeciwdziałania zmianom klimatu czy też zobowiązanie do wdrożenia odpowiedniego ustawodawstwa krajowego. RB może podejmować tego rodzaju działania zarówno wobec państw, jak i przedsiębiorstw ${ }^{39}$. Sankcje przewidziane $\mathrm{w}$ art. $41 \mathrm{KNZ}$ powinny być brane pod uwagę $\mathrm{w}$ ostateczności - gdy środki traktatowe, np. przewidziane w protokole z Kioto, okażą się nieefektywne lub zbyt wolno wdrażane ${ }^{40}$. Ponadto nie można wykluczyć ustanowienia w oparciu o art. 42 lub $40 \mathrm{KNZ}$ mandatu sił pokojowych ONZ w zakresie zmian klimatu, chociażby w związku z przeciwdziałaniem skutkom tych zmian w postaci podnoszenia poziomu mórz i oceanów (np. poprzez budowę zapory). Należy się zgodzić, że w sprawach klimatycznych użycie siły zbrojnej sensu stricto nie wchodzi w grę, jednak w nagłych sytuacjach wykorzystanie wojska w ramach operacji pokojowej ONZ (green

36 Zob. Trail smelter case (USA, Canada), [w:] Reports of International Arbitral Awards, vol. 3, United Nations 2006, s. 1905-1982.

37 Ch.K. Penny, Greening the security council. Climate change as an emerging ,threat to international peace and security”, „International Environmental Agreements. Politics, Law and Economics" 2007, vol. 7, s. 61.

38 A. Knight, Global environmental threats. Can the Security Council protect our Earth?, „New York University Law Review” 2005, vol. 80, s. 1563.

39 Ch. Voight, Security in a ,warming world". Competences of the UN Security Council for preventing dangerous climate change, [w:] Security. A multidisciplinary normative approach, ed. C. Bailliet, Martinus Nijhoff, Leiden 2009, s. 298, 307.

40 A. Knight, Global environmental threats..., s. 1550-1551. 
helmets) może okazać się konieczne, np. w celu ewakuacji ludności czy utrzymania lub przywrócenia bezpieczeństwa na obszarach dotkniętych klęskami żywiołowymi wynikającymi ze zmian klimatu ${ }^{41}$.

\section{Konkluzje}

Z raportów IPCC wynika, że globalne ocieplenie pogłębi problemy związane ze zmianami klimatu. Współpraca międzynarodowa będzie musiała przyspieszyć, chociaż może się okazać, że w pewnym momencie katastrofy klimatycznej prowadzącej do zagłady ludzkości nie uda się już uniknąć. Do tego czasu społeczność międzynarodowa musi sięgnąć po bardziej efektywne metody dyscyplinowania państw w zakresie redukcji emisji gazów cieplarnianych niż tradycyjna dyplomacja oparta na negocjowaniu i ratyfikowaniu traktatów. Doskonałym przykładem szybkiej reakcji RB na zjawiska naturalne są bezprecedensowe zobowiązania nałożone rezolucją nr 2177/2014 na państwa afrykańskie podczas epidemii eboli (np. wymóg ustanowienia krajowych mechanizmów szybkiej diagnozy i leczenia chorych).

Należy zdać sobie sprawę, że powyższe rozważania nadal dotyczą przyszłości. RB, mimo ewolucji w podejściu do klimatycznego wymiaru bezpieczeństwa, daleka jest od wydania rezolucji w sprawie zmian klimatu, która nakładałaby na państwa lub przedsiębiorstwa zobowiązania w zakresie redukcji emisji gazów cieplarnianych. Przyczyną takiego stanu rzeczy jest negatywne stanowisko Rosji i Chin. Państwa UE i Stany Zjednoczone nie sprzeciwiały się jak dotąd poszerzeniu kompetencji Rady o sprawy klimatyczne, co należy uznać za dobry sygnał. Za kilkanaście lat odczuwalne zmiany klimatu mogą doprowadzić do niespodziewanej jednomyślności (jak w przypadku nagłej epidemii), ale może być już za późno. Nad konsensusem należy więc pracować teraz. Myślenie perspektywiczne skłania do akceptacji ewentualnej rezolucji, która może nakładać na państwa obowiązki w zakresie zmian klimatu, szczególnie obecnie, gdy zobowiązania zawarte w protokole z Kioto i porozumieniu paryskim krytykowane są za nieskuteczność, a jednocześnie brakuje ogólnej zasady prawa międzynarodowego zobowiązującej do zmniejszenia emisji gazów cieplarnianych. Nie można oczywiście tracić z pola widzenia innych instrumentów, tj. kompetencji Zgromadzenia Ogólnego ONZ

41 Por. L.A. Malone, ,, Green helmets”. A conceptual framework for Security Council authority in environmental emergencies, „Michigan Journal of International Law” 1996, vol. 17 , issue 2 , s. 532-533. 
i Rady Społeczno-Gospodarczej czy też odpowiednich umów międzynarodowych. Może się jednak okazać, że w konkretnej sytuacji zagrażającej pokojowi i bezpieczeństwu międzynarodowemu (np. związanej z podnoszeniem poziomu mórz i oceanów) narzędzia te będą niewystarczające, zbyt miękkie lub powolne.

\section{Bibliografia}

5663 ${ }^{\text {rd }}$ meeting, Tuesday, 17 April 2007, 10 a.m., New York, United Nations Security Council, S/PV.5663, dostępny w internecie [dostęp: 14 V 2019]: <https://www.securitycouncilreport.org/atf/cf/\%7B65BFCF9B-6D27-4E9C-8CD3-CF6E4FF96FF9\%7D/Ener\%20 SPV\%205663.pdf>.

5663 ${ }^{\text {rd }}$ meeting, Tuesday, 17 April 2007, 3 p.m., New York, United Nations Security Council, S/PV.5663 (Resumption 1), dostępny w internecie [dostęp: 14 V 2019]: <https://www.securitycouncilreport.org/atf/cf/\%7B65BFCF9B-6D27-4E9C-8CD3-CF6E4FF96FF9\%7D/ Ener\%20SPV\%205663\%20Res\%201.pdf>.

6587 th meeting Wednesday, 20 July 2011, 3 p.m., New York, United Nations Security Council, S/PV.6587 (Resumption 1), dostępny w internecie [dostęp: 14 V 2019]: <https://www.securitycouncilreport.org/atf/cf/\%7B65BFCF9B-6D27-4E9C-8CD3-CF6E4FF96FF9\%7D/ CC\%20SPV\%206587\%20RES1.pdf $>$.

Barcik J., Srogosz T., Prawo międzynarodowe publiczne, C.H. Beck, Warszawa 2017.

Climate change 2014. Synthesis report. Contribution of working groups I, II and III to the Fifth Assessment Report of the Intergovernmental Panel on Climate Change, ed. R. K. Pachauri, L.A. Meyer, Intergovernmental Panel on Climate Change, Geneva 2014, dostępny w internecie [dostęp: 14 V 2019]: <http://www.ipcc.ch/report/ar5/index.shtml>.

Climate change and international security. Paper from the High Representative and the European Commission to the European Council, European Commission, [b.d.m.w.], dostępny w internecie [dostęp: 14 V 2019]: <http://www.consilium.europa.eu/media/30862/ en_clim_change_low.pdf $>$.

Climate change and its possible security implications. Report of the Secretary-General, United Nations General Assembly, A/64/350, 11 IX 2009, dostępny w internecie [dostęp: 14 V 2019]: $<$ https://www.unhcr.org/protection/environment/543e73f69/climate-change-its-possible-security-implications-report-secretary-general.html>.

Czapliński W., Wyrozumska A., Prawo międzynarodowe publiczne. Zagadnienia systemowe, C.H. Beck, Warszawa 2004.

Gleick P.H., Water and conflict. Fresh water resources and international security, „International Security" 1993, vol. 18, No. 1.

In hindsight. The Security Council and climate change - an ambivalent relationship, ,Security Council Report" [online], 31 VII 2017 [dostęp: 14 V 2019], dostępny w internecie: <http:// www.securitycouncilreport.org/monthly-forecast/2017-08/the_security_council_and_climate_change_an_ambivalent_relationship.php $>$.

Kenig-Witkowska M., Międzynarodowe prawo środowiska. Wybrane zagadnienia systemowe, Wolters Kluwer Polska, Warszawa 2011. 
Knight A., Global environmental threats. Can the Security Council protect our Earth?, „New York University Law Review" 2005, vol. 80.

Legality of the threat or use of nuclear weapons. Advisory opinion of 8 July 1996, International Court of Justice (ICJ Reports).

Letter dated 5 April 2007 from the Permanent Representative of the United Kingdom of Great Britain and Northern Ireland to the United Nations addressed to the President of the Security Council, United Nations Security Council, S/2007/186, dostępny w internecie [dostęp: 14 V 2019]: <https:/www.securitycouncilreport.org/atf/cf/\%7B65BFCF9B-6D27-4E9C-8CD3-CF6E4FF96FF9\%7D/CC\%20S2007\%20186.pdf>.

Malone L.A., ,, Green helmets”. A conceptual framework for Security Council authority in environmental emergencies, „Michigan Journal of International Law” 1996, vol. 17, issue 2.

Migration, Environment and Climate Change (MECC) Division. Evidence for policy (MECLEP). Glossary, International Organization for Migration, Geneva 2014, dostępny w internecie [dostęp: $14 \mathrm{~V}$ 2019]: <https://publications.iom.int/system/files/pdf/ meclep_glossary_en.pdf?language $=\mathrm{en}>$.

Noack R., Has the era of the 'climate change refugee' begun?, „The Washington Post” [online], 7 VIII 2014 [dostęp: 14 V 2019], dostępny w internecie: <https://www.washingtonpost.com/news/worldviews/wp/2014/08/07/has-the-era-of-the-climate-change-refugee-begun/?noredirect=on\&utm_term=.79e4657212ac $>$.

Państwo i terytorium w prawie międzynarodowym, red. J. Menkes, E. Cała-Wacinkiewicz, C.H. Beck, Warszawa 2015.

Penny Ch.K., Greening the security council. Climate change as an emerging ,threat to international peace and security”, „International Environmental Agreements. Politics, Law and Economics" 2007, vol. 7.

Press conference on impact of climate change on Marshall Islands, „United Nations” [online], 15 II 2013 [dostęp: 14 V 2019], dostępny w internecie: <http://www.un.org/press/ en/2013/130215_MI.doc.htm>.

Provisional rules of procedure. Chapter VI: Conduct of business, „United Nations Security Council” [online, dostęp: 14 V 2019], dostępny w internecie: <https://www.un.org/ securitycouncil/content/rop/chapter-6>.

Resolution 2349 (2017). Adopted by the Security Council at its $7911^{\text {th }}$ meeting on 31 March 2017, United Nations Security Council, S/RES/2349 (2017), dostępny w internecie [dostęp: 14 V 2019]: <https://www.securitycouncilreport.org/atf/cf/\%7B65BFCF9B-6D27-4E9C-8CD3-CF6E4FF96FF9\%7D/S_RES_2349.pdf >.

Resolution 2408 (2017). Adopted by the Security Council at its $8215^{\text {th }}$ meeting on 27 March 2018, United Nations Security Council, S/RES/2408 (2018), dostępny w internecie [dostęp: 14 V 2019]: <https://undocs.org/S/RES/2408(2018)>.

Security Council, in statement, says 'contextual information' on possible security implications of climate change important when climate impacts drive conflict, „United Nations” [online], 20 VII 2011 [dostęp: 14 V 2019], dostępny w internecie: <https://www.un.org/ press/en/2011/sc10332.doc.htm>.

Security Council strongly condemns terrorist attacks, other violations in Lake Chad Basin region, unanimously adopting resolution 2349 (2017), „United Nations” [online], 31 III 2017 [dostęp: 14 V 2019], dostępny w internecie: <https://www.un.org/press/en/2017/ sc12773.doc.htm>. 
Security. A multidisciplinary normative approach, ed. C. Bailliet, Martinus Nijhoff, Leiden 2009.

Srogosz T., Bezpieczeństwo klimatyczne a prawo międzynarodowe, „Zeszyty Naukowe Uczelni Jana Wyżykowskiego. Studia z Nauk Społecznych” 2019, z. 11.

Stallard H., Turning up the heat on Tuvalu. An assessment of potential compensation for climate change in accordance with state responsibility under international law, „Cantenbury Law Review" 2009, vol. 15.

Statement by the President of the Security Council, United Nations Security Council, 20 VII 2011, S/PRST/2011/15, dostępny w internecie [dostęp: 14 V 2019]: <https://www.securitycouncilreport.org/atf/cf/\%7B65BFCF9B-6D27-4E9C-8CD3-CF6E4FF96FF9\%7D/ CC\%20SPRST\%202011\%205.pdf>.

Symonides J., Wyznaczanie granic obszarów morskich w Arktyce. Spory delimitacyjne i ich rozwiązanie, [w:] Państwo i terytorium w prawie międzynarodowym, red. J. Menkes, E. Cała-Wacinkiewicz, C.H. Beck, Warszawa 2015.

Trail smelter case (USA, Canada), [w:] Reports of International Arbitral Awards, vol. 3, United Nations 2006.

Voight Ch., Security in a ,warming world”. Competences of the UN Security Council for preventing dangerous climate change, [w:] Security. A multidisciplinary normative approach, ed. C. Bailliet, Martinus Nijhoff, Leiden 2009.

Warren D., Climate change and international peace and security. Possible roles for the U.N. Security Council in addressing climate change, Columbia Law School, Sabin Center for Climate Change Law, New York 2017, dostępny w internecie [dostęp: 14 V 2019]: <https://web.law. columbia.edu/sites/default/files/microsites/climate-change/warren_-_cc_and_international_ peace_and_security___roles_for_the_un_security_council.pdf $>$.

Warren D., Utterback N., United Nations Security Council holds special meeting on climate change, „Climate Law Blog” [online], 7 VII 2015 [dostęp: 14 V 2019], dostępny w internecie: $<$ http://blogs.law.columbia.edu/climatechange/2015/07/07/united-nations-security-council-holds-special-meeting-on-climate-change/\#more-3336>.

Working methods handbook. „Arria-formula” meetings, „United Nations Security Council” [online, dostęp: 14 V 2019], dostępny w internecie: <https://www.un.org/securitycouncil/ content/arria-formula>. 